\title{
A Public Trust Exception to the Rule of Lenity
}

\author{
Ross E. Davies†
}

The rule of lenity ("Rule") is the canon of statutory construction that requires courts to construe ambiguous penal statutes strictly in favor of the accused. ${ }^{1}$ This Comment will show that the Rule is subject to an unstated exception-an exception supported by the same quasi-constitutional norms as the Rule itself $^{2}$ and reflected in both historical and contemporary practices. ${ }^{3}$ The exception, which this Comment will call the "public trust exception," precludes application of the Rule when the accused holds a public trust and the crime relates to that trust. It allows a court to apply the most reasonable construction of an ambiguous criminal statute instead of the narrower one normally mandated by the Rule. ${ }^{4}$ The public trust exception imports no Chicago.

$\dagger$ B.A. 1984, Washington University; J.D. Candidate 1997, The University of

${ }^{1}$ Smith $v$ United States, 508 US 223, 246 (1993) (Scalia dissenting) (stating the Rule). The courts use the terms "strict" and "narrow" interchangeably to describe the construction of statutes under the Rule. This Comment does the same.

2 Virtually all modern cases discussing or applying the Rule refer to its deep roots in the common law and its two-part, quasi-constitutional substantive bases: due process of law and separation of powers. See Part IV.

3 Strict construction of penal statutes in the eighteenth century was based on judicial aversion to excessive capital punishment. See Part I.A. Modern strict construction is based on the quasi-constitutional norms discussed in note 2. See Parts I.B and I.C.

- This should not be taken to mean that there were, or are, no other exceptions to the Rule. For example, the eighteenth-century cases surveyed in this Comment also might be interpreted to show that women were more likely than men to enjoy the protection of the Rule, or that crimes against children were more likely than crimes against property to go unpunished. Arguments also have been made for additional modern exceptions to the Rule. See, for example, Todd E. Molz, Reining in the Mail Fraud Statute: Statutory Interpretation and Repeal by Implication (unpublished manuscript on file with $\mathrm{U}$ Chi $\mathrm{L}$ Rev) (noting that courts rarely invoke the Rule to narrow the scope of the very broad federal mail fraud statute); Charles Oliver, A Green War on Civil Liberties?, Investor's Bus Daily A1 (Nov 24, 1995) (available in LEXIS) (reporting on theory put forward by Timothy Lynch, assistant director of the Center for Constitutional Studies at the Cato Institute, that there is a "regulatory exception" to the Rule in cases involving complex environmental regulations).

These theories, combined with the one offered in this Comment and perhaps others yet to be developed, might swallow the Rule, converting it into a disjointed set of contextually discrete and particular conditions under which narrow construction of penal statutes would be appropriate. For a related discussion making a broader argument for 
new substance into a statute, or into the Rule. It simply frees a court from the constraints of the Rule in cases where the established rationales for the Rule do not apply. Although there are relatively few cases involving defendants who hold public trusts in the reporters of the eighteenth-century English courts, where the Rule developed, or the modern federal courts, where the Rule is still a regular subject of deliberation, those that are reported point toward the existence of the public trust exception to the Rule.

This Comment, then, does not propose any radical change in legal practice under the Rule. Instead, it describes an established, but unstated and unexplained, exception to the Rule and argues that the exception makes sense in light of the quasiconstitutional rationales for the Rule itself. The Comment does, however, call for one small but significant change in current practice-explicit announcement and explanation of the public trust exception in opinions applying it. There are at least four reasons why courts should publicly embrace the exception: (1) it will yield better, more consistent adjudication by encouraging consistent use of the exception and discouraging inappropriate application of the Rule; (2) it will put the exception in the legal record, where all law belongs; (3) it will enhance the credibility of the Rule by putting an understandable and reasonable limit on it; and (4) it will resolve any doubts about fair notice to public trust defendants. In addition, publicly embracing the exception may help to address the concern voiced by public choice theorists that legislators often have incentives to be deliberately ambiguous when passing laws, including penal statutes. ${ }^{5}$

complete abandonment of the Rule, see generally Dan M. Kahan, Lenity and Federal Common Law Crimes, 1994 S Ct Rev 345 (arguing that the Rule should be abolished in favor of limited delegation of criminal lawmaking to the courts). Professor Kahan's standard for interpretation of criminal statutes resembles the standard applied under the public trust exception. Compare id at 396-97 ("[C]ourts should adopt the best readings of incompletely specified criminal statutes.") with text accompanying this note (Courts should "apply the most reasonable construction of an ambiguous criminal statute."). This Comment, although not necessarily inconsistent with Professor Kahan's thesis, is limited to identifying just one area in which, in most cases, the "best" readings of statutes already do prevail over the readings that would result from application of the Rule. This Comment takes no position on the merits of preserving or doing away with the Rule; rather, it presumes that for as long as the Rule does remain a part of American law, it should be clearly understood and legally, sensibly, and consistently applied.

${ }_{5}$ See generally Daniel A. Farber and Philip P. Frickey, Law and Public Choice: $A$ Critical Introduction (Chicago 1991). For such a critique in the context of penal laws, see, for example, Donald A. Dripps, Criminal Procedure, Footnote Four, and the Theory of Public Choice; or, Why Don't Legislatures Give a Damn about the Rights of the Accused?, 
Part I of this Comment provides an overview of the history and current status of the Rule and the shape of the public trust exception. Part II addresses the relevance of old English cases to modern application of the Rule. Part III analyzes the results of a survey of criminal cases from 1730 to 1791 reported in 168 English Reports, ${ }^{6}$ highlighting evidence of the public trust exception. This Part then analyzes 1991 and 1992 cases from the United States federal courts in which the Rule was a factor, ${ }^{7}$ focusing on parallels to the English survey. Part IV applies the two main substantive rationales for the Rule-quasi-constitutional due process and separation of powers-to the exception, and addresses two of the strongest objections to it. Part V reviews the Supreme Court's decision in McNally $v$ United States, ${ }^{8}$ which misapplied the Rule in a public trust case, and its aftermath. The Comment concludes with a revised statement of the Rule, a statement that incorporates the public trust exception.

\section{THE MODERN RULE, ITS HISTORY, AND THE PUBLIC TRUST EXCEPTION}

\section{A. History of the Rule}

The Rule was born in England. ${ }^{9}$ Examples of something that looks like the Rule can be found at least as far back as the mid-sixteenth century, ${ }^{10}$ and the Rule was sufficiently well established by the mid-seventeenth century to be considered a "general position" of criminal law by Sir Matthew Hale. ${ }^{11}$

44 Syracuse L Rev 1079 (1993).

B 168 Eng Rep 103-374 (1730-1791) (reporting 244 cases, about half of which are clearly trials or appeals involving statutory crimes). For an explanation of why the Leach reporter was selected, see note 51 .

7 For an explanation of why the 1991 and 1992 cases were selected, see note 78.

B 483 US 350 (1987).

The Rule has far more ancient antecedents than the common law of England. See, for example, Geoffrey P. Miller, Pragmatics and the Maxims of Interpretation, $1990 \mathrm{Wis} \mathrm{L}$ Rev $1179,1189-90$ \& nn 47-48 (identifying a parallel between the Rule and a maxim in the Digest of Justinian). But the legal roots of today's Rule are English.

10 See, for example, Blackstone's famous account of a case in which an English court interpreted a 1547 statute criminalizing the stealing of "horses" to be inapplicable to a defendant who stole just one horse. William M. Blackstone, 1 Commentaries $* 88$. Parliament enacted a new statute the following year to cover one-horse thieves. Id.

${ }^{11}$ See Matthew Hale, 2 The History of the Pleas of the Crown 335 (Professional 1980) (text modernized):

That where any statute ... has ousted clergy in any of those felonies, it is only so far ousted, and only in such cases and as to such persons, as are expressly comprised within such statutes, for in favorem vitz \& privilegii clericalis such statutes are con- 
The Rule flowered in the eighteenth century in response to the rapid expansion of the category of capital offenses. ${ }^{12}$ As Parliament enacted dozens of statutes applying the death penalty to offenses ranging from the serious to the nearly trivial, ${ }^{13}$ the English courts increasingly used the Rule to save lives that would otherwise have been snuffed out for transgressions which, in the eyes of the judiciary, did not merit capital punishment. ${ }^{14}$ The Rule served, in effect, as a mechanism for judicial nullification of excessively punitive statutes, ${ }^{15}$ with protection of life as its substantive rationale. ${ }^{16}$

The Rule was imported into American law via United States $v$ Wiltberger, ${ }^{17}$ which remains a frequently cited authority for the Rule. However, the original English rationale-protection of life from exceedingly bloody statutes-did not cross the Atlantic with the Rule; or, if it did, it was radically transformed in the process. While the English Rule protected defendants from excessive capital punishment resulting from inordinate legislative brutality, the American Rule protected defendants from punishment of all sorts resulting from statutory ambiguity. ${ }^{18}$ General-

strued literally and strictly.

See also Matthew Hale, 1 The History of the Pleas of the Crown 469-70 (Professional 1980), reporting and commenting on Williams' Case (1639), in which a statute declaring manslaughter a capital crime under certain conditions was narrowly construed.

${ }_{12}$ See Jerome Hall, Theft, Law and Society 114-18 (Bobbs-Merrill 2d ed 1952); Leon Radzinowicz, 1 A History of English Criminal Law and its Administration from 1750: The Movement for Reform 83-90 (Stevens \& Sons 1948).

13 For illuminating juxtapositions of capital crimes, see Radzinowicz, 1 History of English Criminal Law at 10-11 (cited in note 12) (citations omitted):

(1) murdering the king or levying war against the king in his realm, and marking the edges of any current coin of the kingdom; (2) murder, and maliciously cutting any hop-binds growing on poles in any plantation of hops; (3) riotously assembling and demolishing a church or chapel, and the wandering about of soldiers or mariners without a pass; (4) maiming or wounding officers going on board ship in execution of their excise duties, and pocket-picking to the amount of twelve pence and over; (5) rape, and destroying the heads of fish-ponds; (6) serious forgery on the Bank of England, and being in the company of gypsies.

14 See John H. Langbein, Shaping the Eighteenth-Century Criminal Trial: A View from the Ryder Sources, 50 U Chi L Rev 1, 36-41 (1983) (summarizing the evolution of benefit of clergy, capital punishment, and transportation in pre-nineteenth-century England). See also Hall, Theft, Law and Society at 118-32 (cited in note 12).

${ }_{15}$ See Hall, Theft, Law and Society at 118 (cited in note 12). Other institutional players also contributed to nullification. Id at 124,130 (describing roles played by juries and prosecutors).

${ }^{16}$ See Hale, 2 History of the Pleas of the Crown at 335 (cited in note 11).

1718 US (5 Wheat) 76, 95 (1820).

${ }^{18}$ Id at 95 . For example, in Wiltberger, the Court interpreted its jurisdiction narrowly 
ly, though, both versions of the Rule used strict statutory construction to protect defendants from imperfect legislation. ${ }^{19}$

In Wiltberger, the Supreme Court defined the Rule, and located its American basis in two important quasi-constitutional norms: due process of law and separation of powers. Chief Justice John Marshall provided the definitive nineteenth-century statement of these norms:

The rule that penal laws are to be construed strictly, is perhaps not much less old than construction itself. It is founded on the tenderness of the law for the rights of individuals; and on the plain principle that the power of punishment is vested in the legislative, not in the judicial department. ${ }^{20}$

Once settled in the New World, the Rule was essentially etched in stone, and appears in modern reports unchanged save for updated language. Justice Thurgood Marshall provided the modern statement:

This principle is founded on two policies that have long been part of our tradition. First, a fair warning should be given to the world in language that the common world will understand, of what the law intends to do if a certain line is passed. To make the warning fair, so far as possible the line should be clear. Second, because of the seriousness of criminal penalties, and because criminal punishment usually represents the moral condemnation of the community, legislatures and not courts should define criminal activity. ${ }^{21}$

rejecting a manslaughter charge. Id at 105-06.

10 The shift in rationales accompanying the Rule's adoption in the United States may have been due in part to widespread reform of penal codes during the years immediately before and after ratification of the Constitution, including a significant reduction in the number of capital crimes in many states. See Lawrence M. Friedman, A History of American Law 280-83 (Simon \& Schuster $2 \mathrm{~d}$ ed 1985) (describing the course, and mixed results, of "a wide[ ] movement to reduce the number of capital crimes, reform the penal code, and, if possible, get rid of the death penalty altogether"); Model Penal Code and Commentaries 123-29 (ALI 1980) (discussing Pennsylvania's watershed reform of homicide law in 1794, and related developments). During this period of rapid and widespread legislative experimentation, the Rule, as an established tool for judicial tempering of legislative excesses, may have simply expanded from a canon of particular application to one of general application, from rigidity in the service of nullification to narrowness in the service of due process, but still in the name of protecting the accused from legislative imperfection. For a general discussion of how legal doctrines change over time, see Oliver Wendell Holmes, The Common Law 37 (Little, Brown 1951) ("[I]f old implements could not be adjusted to new uses, human progress would be slow.").

${ }^{20}$ Wiltberger, 18 US (5 Wheat) at 95.

21 United States $v$ Bass, 404 US 336, 348 (1971) (citations omitted). These norms may 
Developed as an instrument to prevent capital injustice in eighteenth-century England, the Rule-the practice of narrow construction of ambiguous penal statutes-was adopted in the same spirit by the United States to protect liberty and property, as well as life.

\section{B. The Modern Rule}

Justice Frankfurter coined the phrase "rule of lenity" in $1958^{22}$ to denote the centuries-old rule of statutory construction requiring courts to "resolve doubts in the enforcement of a penal code against the imposition of a harsher punishment." 23 Since then, largely unchanged except for the widespread adoption of its new "rule of lenity" moniker, the Rule has been discussed in hundreds of federal cases ${ }^{24}$ and has been dispositive (or at least an important factor) in at least a few, including several in the Supreme Court. ${ }^{25}$ Today, the Rule derives its force from two sources: its historic common law roots and the two quasi-constitutional norms-due process of law and separation of powers-articulated in Wiltberger and hundreds of subsequent cases.

The Rule has been the subject of considerable debate in the Supreme Court and in legal academia. In just the last few years, all nine sitting Justices have written or joined opinions applying

not have been important to, or even contemplated by, the eighteenth-century English judges. On those occasions when the judges, discussing or applying the Rule, made reference to a norm, it was usually a preference for preserving life.

22 Gore $v$ United States, 357 US 386, 391 (1958). The new terminology caught on quickly. The first federal circuit court decision to use it was Papalardo $v$ United States, 260 F2d 326, 328 (6th Cir 1958). The first district court opinion to do so was United States $v$ Callanan, 173 F Supp 98, $100 \& \mathrm{nn} 2,3$ (E D Mo 1959). The association of the word "lenity" with the rule that ambiguous penal statutes should be construed narrowly in favor of the defendant predates Gore by at least a century, during which it was used intermittently. See, for example, Ex parte Davis, 7 F Cas 45, 49 (N D NY 1851) ("[W]henever any ambiguity arises in a statute, introducing a new penalty or punishment, the decision shall be on the side of lenity and mercy.") (citations omitted); United States $v$ Turley, 352 US 407, 418 (1957) (Frankfurter dissenting) (referring to "the principle of lenity").

23 Bell $v$ United States, 349 US 81, 83 (1955) (cited in Gore).

${ }_{24}$ With the advent of the Federal Sentencing Guidelines, the Rule has been expanded to apply to the Guidelines, as well as penal statutes and cognate civil statutes. See, for example, United States $v$ Granderson, 114 S Ct 1259, 1267 (1994). A LEXIS search conducted on April 2, 1996, for post-Gore references to the "rule of lenity" generated 890 cases at all levels of the federal judiciary. The Rule is also an important canon of construction in state courts (the same LEXIS search revealed 577 state cases discussing the Rule). The results of the LEXIS search are on file with U Chi L Rev.

${ }^{25}$ See, for example, Granderson, $114 \mathrm{~S}$ Ct at 1267; Dowling $v$ United States, 473 US 207, 229 (1985); Simpson v United States, 435 US 6, 14-15 (1978); United States $v$ Bass, 404 US 336, 347 (1971). 
or arguing for application of the Rule and all nine have had occasion to critique, sometimes in sharp terms, each other's definition and application of the Rule. ${ }^{26}$ Scholars continue to challenge not only the function and utility of the Rule, but the merits of its continued existence. ${ }^{27}$ Few of its critics, however, deny entirely the Rule's continuing influence, ${ }^{28}$ and given the (at least occasional) support for the Rule by all sitting members of the Supreme Court, it appears to be an established element of American law.

In sum, the Rule is a durable and long-lived canon of statutory construction that was influential in the eighteenth century and remains so today. On occasion, it still controls the outcomes of cases, and thus it still matters to modern criminal (and, in some cases, civil $^{29}$ ) defendants.

26 See, for example, United States $v$ Aguilar, 115 S Ct 2357, 2362-63, 2368 (1995) (Rehnquist, for a majority including O'Connor, Souter, Ginsburg, and Breyer; and Scalia, joined by Kennedy and Thomas, concurring in part and dissenting in part, debating the standards for invoking the Rule); Granderson, $114 \mathrm{~S} \mathrm{Ct}$ at 1267-68 \& n 12, 1276, 1280 (Ginsburg, for a majority including Blackmun, Stevens, O'Connor, and Souter, applying the Rule; and Rehnquist, joined by Thomas, dissenting, disagreeing about the ambiguity necessary to invoke the Rule); Smith $v$ United States, 508 US 223, 239-41, 246-47 (1993) (O'Connor, for a majority including Rehnquist, White, Blackmun, Kennedy, and Thomas; and Scalia, joined by Stevens and Souter, dissenting, differing sharply on the scope of the Rule); United States v R.L.C., 503 US 291, 306 n 6, 307-12, 314 (1992) (Souter, for the Court, declining to apply the Rule; Scalia, joined by Kennedy and Thomas, concurring in part and concurring in the judgment, arguing for application of the Rule; Thomas, in a separate concurrence, arguing for application; and O'Connor, joined by Blackmun, dissenting, all taking different positions on the limits of the Rule).

27 Kahan, 1994 S Ct Rev at 396-425 (cited in note 4) (arguing that "[l]enity should be abolished"); John Calvin Jeffries, Jr., Legality, Vagueness, and the Construction of Penal Statutes, 71 Va L Rev 189, 244 (1985) ("What is left of strict construction is . . . little more than a makeweight to be invoked or discarded as the occasion demands."); United States $v$ Nofziger, 878 F2d 442, 456 (DC Cir 1989) (Edwards dissenting) ("Although the rule is a widely accepted theoretical notion, my review of the nearly one hundred federal cases in which reviewing courts in the last ten years have paid lip service to the principle reveals that, almost without exception, courts have found the rule to be altogether inapplicable to the facts before them."). But see Sarah Newland, Note, The Mercy of Scalia: Statutory Construction and the Rule of Lenity, 29 Harv CR-CL L Rev 197, 205-13, 228-29 (1994) (calling for broader application of the Rule). Judge Posner has observed that the Rule has "arguable merit" as a tool for limiting overdeterrence under vague penal statutes. Richard A. Posner, The Federal Courts: Crisis and Reform 283-84 (Harvard 1985).

${ }_{23}$ See, for example, Nofziger, 878 F2d at 456 (Edwards dissenting) (acknowledging that "no one would deny that the specter of the rule of lenity has had a significant impact on the operation of our democracy"); Kahan, 1994 S Ct Rev at 346-47 (cited in note 4) (noting that the Rule "tells us a lot" about the criminal law, even though it is "about as effective in constraining Congress's power to shift criminal lawmaking power to courts as the now dormant 'nondelegation doctrine' is in constraining Congress's power to shift regulatory-lawmaking authority to administrative agencies").

${ }_{29}$ In a few instances, the Rule has been dispositive in civil cases that might affect, or require interpretation of, cognate criminal statutes, see, for example, United States $v$ 


\section{The Public Trust Exception}

The "public trust exception," although unstated and unacknowledged, is practically as old as the Rule itself. It denies to a defendant the benefit of the Rule when the defendant is accused of a criminal violation related to her public trust. ${ }^{30}$ As a result, a court may choose the broader, rather than the narrower, construction of the statute if confronted by (a) a defendant accused of criminal wrongdoing connected to her public trust and (b) an ambiguous penal statute that is subject to two reasonable constructions. The defendant might therefore be convicted of a crime of which she would not have been guilty if she had not been acting pursuant to a public trust.

This does not mean that criminal violators of public trusts are punished for conduct that they are surprised to learn is criminal. Rather, it merely means that a court, recognizing the public trust exception, does not apply the Rule, and instead chooses the most reasonable, rather than a narrower reasonable, interpretation of the statute. ${ }^{31}$ The most reasonable interpretation is, of course, not one that should surprise the holder of a public trust that is governed in part by the statute in question. ${ }^{32}$

\section{Why DOES History MATTER?}

Before considering the results of the survey of eighteenthcentury English cases, we should be clear about why these old cases matter to application of the Rule today.

History matters to modern application of the Rule because the judges and justices who apply it say so. They do so in at least two ways: (1) history is frequently a factor in debates over canons

Thompson/Center Arms Co., 504 US 505, 518 (1992), and an important factor in others. See, for example, Crandon v United States, 494 US 152, 158, 168 (1990). Problems with applying the Rule to civil statutes are not important for the discussion in this Comment. For a thoughtful discussion of the subject, see generally Bruce A. Markell, Bankruptcy, Lenity, and the Statutory Interpretation of Cognate Civil and Criminal Statutes, 69 Ind L J 335 (1994).

so A "public trust" is a trust conferred by a public authority for a public purpose. For discussion of the definition of "public trust," see Part III.A.

${ }^{31}$ The term "most reasonable" has no special meaning here. It simply refers to courts going about their business in the usual way, with access to all the constitutions, statutes, regulations, procedures, canons (except the Rule), and other rules and tools that they normally apply. See also Kahan, 1994 S Ct Rev at 397 (cited in note 4) (arguing for the "best" construction of ambiguous penal statutes in all cases) (emphasis omitted).

${ }^{32}$ See the discussions of notice in Parts IV.A.1 and IV.B.2, and of McNally in Part V. Problems of excessive, or at least secretive, judicial discretion and unmanageable standards may be issues here, but they are inherent in the Rule itself. 
of construction and terms of art developed at common law; and (2) historical support is a significant element of the judicial rhetoric justifying the existence and importance of the Rule. History also matters from a practical standpoint, to the extent that historical acceptance of the Rule bolsters the credibility of the judicial actors who invoke it, and does so especially in the context of the public trust exception.

Common law history-English as well as American-has been an important factor in a range of cases, ${ }^{33}$ and is occasionally the subject of heated debate. ${ }^{34}$ The Court has considered the English common law roots of American law in cases ranging from the definition of cruel and unusual punishment, to the equalfooting doctrine, to the guarantee of a public trial, to competency to stand trial, to the scope of habeas corpus review. ${ }^{35}$ History is also significant in this context in a more general way, since the common law is a creature of history, and "[t]his rule of lenity [is] a part of our common law."36

Moreover, when they debate or apply the Rule, the Supreme Court and other courts often refer to it in terms that link its significance and force to its antiquity. For example, in United States $v$ R.L.C., both the plurality and the concurring Justices referred to the Rule in terms emphasizing its seniority, citing "the venerable rule of lenity," "the ancient requirement that criminal statutes speak plainly and unmistakably,"38 and "long-

${ }^{33}$ See, for example, Evans $v$ United States, 504 US 255, 260-62 (1992) (affirming extortion conviction under the Hobbs Act based on an interpretation of nineteenth-century English and American common law terms in the statute). But see Harmelin v Michigan, 501 US 957, 966-75 (1991) (reviewing English history of "cruell and unusuall punishments, " but concluding that the definitive meaning was to be found in the understanding of the Americans who ratified the Eighth Amendment).

34 See, for example, Evans, 504 US at 271 n 23, 278-87 (Justices Stevens and Thomas trading barbs over each other's alleged misuse of common law history).

${ }^{35}$ For the use of English common law history in understanding the meaning of cruel and unusual punishment, compare Harmelin, 501 US at 975 (discounting the significance of English common law history) with Solem v Helm, 463 US 277, 284-86 (1983) (emphasizing that the principle of proportionality is "deeply rooted ... in common-law jurisprudence"). For use of common law history in other contexts, see, for example, Utah Division of State Lands v United States, 482 US 193, 195-96 (1987) (equal-footing doctrine); Richmond Newspapers $v$ Virginia, 448 US 555, 573 n 9, 589-90 (1980) (public-trial guarantee); Godinez v Moran, 509 US 389, 404-05 (1993) (Kennedy concurring in part and concurring in the judgment) (competency to stand trial); Engle $v$ Isaac, 456 US 107, 126, 135 (1982) (habeas corpus review).

36 Tarpley v Dugger, 841 F2d 359, 364 (11th Cir 1988) (citations omitted).

37503 US 291, 305 (1992).

${ }^{38} 503$ US at 310 (Scalia concurring) (citation omitted). 
standing principles of lenity." ${ }^{39}$ In other recent cases, the Court has referred to "the time-honored . . . [rule] of lenity," "the traditional rule of lenity,"41 and "the established rule of ... lenity." 42

The deep history of the Rule is also important to at least one Justice as a restraint of sorts on its application. Justice Scalia has implied, albeit not in a judicial opinion, that today's judges do not apply the Rule as intrusively as the eighteenth-century English judges did: "I doubt, for instance, that any modern court would go to the lengths described by Blackstone in its application of the rule that penal statutes are to be strictly construed." ${ }^{34}$ If, in fact, modern courts view their application of the Rule as bounded at one extreme by the behavior of their eighteenth-century English predecessors, then historical evidence of a public trust exception (or any other exception) to the Rule would require the courts to either accept the exception or rethink their conception of, and rationales for, the boundaries of the Rule.

Finally, history, and especially the history of the public trust exception, could have an impact on the credibility of judicial opinions dealing with public trust cases. There is nothing incredible about a judge, or a Justice, saying with a straight face:

Senator Smith deserves the benefit of the ancient rule of lenity that applies to all defendants.

The same thing probably cannot be said of a judge or Justice who says:

The ancient rule of lenity held people responsible for a public trust to an elevated but reasonable standard when acting in their public trust capacities. Contrary to that standard-a standard that presumed that the people responsible for serving the public knew and obeyed the spirit of at least those rules that applied to their own public duties-this court believes that Senator Smith deserves a break. So, we hereby expand the historic scope of the Rule so that we can adopt a narrow interpretation of this fraud statute.

${ }^{39}$ Id at 308, quoting Hughey $v$ United States, 495 US 411, 422 (1990).

10 United States $v$ Kozminski, 487 US 931, 952 (1988). See also Rewis v United States, 401 US 808, 812 (1971); Dowling $v$ United States, 473 US 207, 229 (1985).

4 Whalen $v$ United States, 445 US 684, 703 (1980) (Rehnquist dissenting) (internal quotation marks omitted).

42 Simpson v United States, 435 US 6, 14 (1978) (internal quotation marks omitted).

43 Antonin Scalia, Assorted Canards of Contemporary Legal Analysis, 40 Case W Res L Rev 581, 582 (1990). 
While the contrast between these two hypothetical decisions highlights an argument for judicial restraint based on the history of the Rule and the public trust exception, it does not lead to an extended "originalist" argument that modern Americans are bound by a definition of "public trust" held by a dead hand from another country. Rather, it militates for an argument that to change the scope-the meaning - of the Rule and its public trust exception requires a reason related to their operation: a change in language, or some other element of context, ${ }^{44}$ such as a change in our culture that would support a less dutiful relationship between holders of public trusts and their communities. A serious argument that citizens of the United States in 1996 are ready to voluntarily embrace a lower standard of accountability for holders of public trusts than were their predecessors is simply not persuasive. Mere public awareness of the public trust exception, then, should establish an informal limit on judicial discretion under the Rule.

\section{SURVEY RESULTS: THE ENGLISH ROOTS AND MODERN USES OF THE PUBLIC TRUST EXCEPTION}

Judicial opinions and scholarly essays may illuminate the reasons for various treatments of the Rule, but to a defendant nothing is more important than the outcome of the case. And the outcomes of the cases, old and new, offer little support for the idea that the Rule is applied uniformly to all defendants. When individuals who hold public trusts are accused of crimes connected to those trusts, they almost never get the benefit of the Rule. When they do, it is against the background of other laws or sanctions that fill most or all of the gaps between the consequences of prosecution (or sentencing) with and without the Rule..$^{45}$ Before considering the support for this argument from the case surveys, however, a working definition of public trust is necessary.

\section{A. Definition of "Public Trust"}

A "public trust" is one "conferred by public authority for a public purpose." This broad definition embraces not only gov-

" See Lawrence Lessig, The Limits of Lieber, 16 Cardozo L Rev 2249 (1995) (discussing fidelity, changing contexts, and meaning).

45 For examples of gap-filling cases, see text accompanying notes 66-69 (eighteenthcentury example) and text accompanying notes 87-88 (modern example).

${ }^{46}$ Missouri Ozarks Economic Opportunity Corp v Long, 763 SW2d 381, 383 (Mo Ct App 1989). See also 35A Words and Phrases 12-15 (West Perm ed 1963 \& Supp 1995). 
ernment officials and employees, but also individuals, including lawyers, those working in the private sector under government licenses or mandates, and, under certain conditions, private citizens whose acts or roles induce public reliance on their good faith performance. ${ }^{47}$ This broad, and highly contextual, conception of public trust is shared at least in part by the legal cultures of eighteenth-century England and modern America. For example, in The King $v$ Waite, the trial court heard an argument that a bank clerk handling government bonds held a "trust [ ] in some measure directed by the Legislature," ${ }^{\prime 4}$ and in United States $v$ $L a m b$, a letter carrier's sentence for embezzlement of mail was enhanced because his position was one of public trust. ${ }^{49}$ In Dixson $v$ United States, the Supreme Court ruled that the officers of a private, nonprofit organization administering federal housing grants were public officials holding a "public trust," and that the definitions included in a criminal statute they were charged with violating were sufficiently clear to preclude application of the Rule:

To determine whether any particular individual falls within this category, the proper inquiry is not simply whether the person has signed a contract with the United States or agreed to serve as the Government's agent, but rather whether the person occupies a position of public trust with official federal responsibilities. ${ }^{50}$

The term "trust" is subject to a variety of interpretations. For a spirited debate on the subject, see United States v Margiotta, 688 F2d 108, 120-26 (2d Cir 1982) (majority arguing for broad interpretation of fiduciary duty to the public); id at 139-44 (Winter concurring in part and dissenting in part) (arguing for narrower treatment).

The arguments in this Comment are simplified by the fact that almost all of the public trust cases cited actually involve violations of those trusts. This may indicate that the courts recognize, at some level, what they are doing and therefore identify the characteristics of the defendants that are relevant to the outcomes of the cases (or at least to the application of the Rule). Or it may indicate that people who hold public trusts are more likely to violate, or be prosecuted for violating, statutes that have to do with their public trust roles than they are to violate, or be prosecuted for violating, other sorts of laws.

${ }_{47}$ See, for example, United States $v$ Post, 25 F3d 599, 600-01 (8th Cir 1994) (holding that a lawyer abused his trust in an insurance fraud scheme because his status as a licensed attorney shrouded his claims with a presumption of regularity); Dixson $v$ United States, 465 US 482, 496-97 (1984) (holding that officers of a private social service organization that administered federal block grants abused their public trust by extracting kickbacks); Margiotta, 688 F2d at 121-22 (holding that an influential local political party chairman held a public trust because he had de facto control over some government decisions).

43168 Eng Rep 117, 118 (KB 1743).

496 F3d 415, 421 (7th Cir 1993).

Bo 465 US 482, 496-97 (1984). See also Margiotta, 688 F2d at 123-26 (discussing at 
Although it might be arguing too much to say that "public trust" meant the same thing in the eighteenth century as it does today, the basic conception appears sufficiently similar in the two eras for this Comment to sort cases based on a broadly parallel understanding of "public trust."

\section{B. 168 Eng Rep, 1730-1791: Summary of Eighteenth-Century Results}

A survey of cases decided between 1730 and 1791, reported by Thomas Leach in 168 English Reports (1 Leach), ${ }^{51}$ shows that the public trust exception was a companion to the Rule throughout much of the eighteenth century. ${ }^{52}$ Leach's reporter also underscores the widely accepted characterization of the development and early application of the Rule, "reveal[ing] the extremes to which the judges went to invent technicalities in order to avoid infliction of the capital penalty." ${ }^{53}$ Of the more than one hundred statutory criminal cases in the Leach survey in which the courts had the opportunity to save a defendant via the Rule, ${ }^{54}$

length the line-drawing problems in the definition of a fiduciary duty to the public).

${ }^{51}$ The first volume of Leach's reporter, which is republished in 168 English Reports, was selected as the sample for this study arbitrarily but not irrationally. A researcher might have turned instead to any one of a number of other respectable reporters covering all or part of that period, for example, Freeman's Reports or Howell's State Trials. However, the Leach reports, especially the first volume, are heavily cited in leading works discussing the Rule. See, for example, Hall, Theft, Law and Society at 118-22 (cited in note 12) (citing, summarizing, and analyzing at length eight cases from Leach's first volume to illustrate the Rule); Radzinowicz, History of English Criminal Law at 788-93 (cited in note 12) (table of cases including more than fifty cases from the same volume). See also William S. Holdsworth, 6 A History of English Law 557, 559 (Little, Brown 1924) (describing Leach's performance as a reporter as "considerable" and remarking on the "improved character of the reports of this period").

Leach, like most reporters in the age before professional or court-sponsored reporters were common, was a prominent member of the bar. Leach describes himself as "Thomas Leach, Esq., of the Middle Temple, Barrister at Law." 168 Eng Rep 103.

${ }_{52}$ See note 64 (listing public trust exception cases spanning 1730 to 1786).

$\$$ Hall, Theft, Law and Society at 123 (cited in note 12) (summarizing a survey of cases mostly from Leach).

54 The eighteenth-century judges rarely announced their application of the Rule. This lends a little of the air of a seance to any effort to determine when a court was contemplating the Rule as it made a decision. The tendency of even the finest legal historians to discuss the existence, prevalence, and attributes of the Rule merely by listing examples illustrates the difficulty of drawing lines between what a modern mind might view as a moderate eighteenth-century interpretation of a statute, a narrow but reasonable eighteenth-century statutory interpretation, and an outrageous eighteenth-century manipulation of the Rule. For examples, see Hall, Theft, Law and Society at 118-26 (cited in note 12). Lacking a better measure, $I$ attempted a two-hundred-year-ex-post application of the Rule: If a court discussed a statute in terms indicating a concern about ambiguity, and then adopted an avowedly or obviously narrow construction, it is treated as a case in- 
they did so in fifty-seven-more than 52 percent of the time. ${ }^{55}$ For example, in The King $v$ Kemp, the defendant was found not guilty of violating a statute prohibiting the theft of plants at night. $^{56}$ The court rested its holding on the observation that if there was sufficient illumination for the witness to identify the features of the defendant, then there was too much daylight for it to have been night. Therefore, the thief could not have been stealing the plants at night. ${ }^{57}$ Although the crime was witnessed at 9:30 p.m., the court did not mention moonlight, starlight, or lamplight. Similarly, in The King $v$ Cook, the defendant, charged with stealing a cow, was found not guilty of larceny. ${ }^{58}$ The court rested its holding on the fact that, although the bovine beast stolen by the defendant was a two-and-one-half-year-old female, it had never had a calf and was, therefore, properly described as a "heifer," and a "heifer" is not a "cow." Therefore, the defendant had not stolen a "cow," and was not guilty of the crime of which he had been accused. ${ }^{59}$

Defendants accused of violating their public trusts do not figure in cases of exaggerated strict construction like those summarized above. More typical of the circumstances of the public trust defendants is the case of The King $v$ Shaw, in which the defendant, a post office letter sorter, had been convicted of stealing a letter that contained a bank note. ${ }^{60}$ On appeal, Shaw urged the court to construe the relevant statutes strictly, arguing that the statutes and the criminal charges were not identical. The court, while it accepted the defendant's argument, refused to release him because it construed the same statutes more liberally against him on other charges of which he had been acquitted in the court below, and concluded that he might yet be convicted.

volving application of the Rule. I also applied the venerable "straight face test": If a reader couldn't restrain his incredulity while reading the statutory interpretation in a case-that is, if it seemed to be the sort of reasoning that belonged in the same category with Hall's parade of ridiculous cases, id, I likewise treated it as a case involving application of the Rule.

${ }_{65}$ The study in this Comment is limited to cases interpreting capital statutes, since those are the cases that, in the eighteenth century, triggered application of the Rule. See Hall, Theft, Law and Society at 118-32 (cited in note 12). In many criminal cases, Leach does not even refer to a "statute" generally. Because they make evaluation of a statutory construction impossible, such cases are excluded from the survey.

${ }^{56} 168$ Eng Rep 213, 213 (KB 1780). The statute was 6 Geo 3, ch 36.

${ }^{57} \mathrm{Kemp}, 168$ Eng Rep at 214.

s8 168 Eng Rep 155, 155 (KB 1774). The indictment was based on two statutes, 14 Geo 2, ch 6, and 15 Geo 2, ch 34 .

39 Cook, 168 Eng Rep at 155.

60 168 Eng Rep 142, 142 (KB 1771). 
Shaw died in prison awaiting trial. ${ }^{61}$ Sharper restrictions on application of the Rule than Shaw are reported by Leach, ${ }^{62}$ but this case captures both sides of the public trust exception in action: courts were reluctant to give public trust defendants the benefit of the Rule in the first place, and, even when the Rule appeared, its application was restrained in ways that left room for outcomes generally inconsistent with what the Rule would have directed had the case not involved a public trust defendant.

The difference in tone and outcome of the cases summarized above is borne out in the bulk of the cases reported by Leach. The decisions show that defendants accused of crimes relating to a public trust almost never received the benefit of the Rule and, in the few instances in which the Rule was applied, dire consequences nevertheless awaited the defendants through alternative legal means. In contrast, the general run of non-public trust criminal defendants enjoyed the benefit of the Rule more than 50 percent of the time.

Table 1: Comparison of Rates of Rule Application in "Public Trust Cases" and "All Other Cases"

\begin{tabular}{||l|c|c||}
\hline & Public Trust Cases & All Other Cases \\
\hline Cases with Statute & 8 & 110 \\
\hline Rule Not Applied & $7^{64}$ & 53 \\
\hline
\end{tabular}

61 Id at $142-43$.

62 See, for example, The King $v$ Hassel, 168 Eng Rep 103, 105 (KB 1730) (emphatically, and at length, declining to apply the Rule).

63 This table includes all of the capital statutory criminal cases reported in Leach (1730 to 1791). A complete table of cases is on file with $U$ Chi L Rev.

6s Hassel, 168 Eng Rep at 105 (Although acquitted, a letter sorter was denied the benefit of the Rule because the court accepted the prosecutor's argument that "penal statutes ought to receive a strict construction; but they must also be construed according to sound reason, common sense, and the apparent intention of the Legislature."). This is the only case in which a court explicitly rejected application of the Rule as a basis for acquittal or discharge. For other cases not applying the Rule, see The King $v$ Gibson, 168 Eng Rep 133 (KB 1766) (A lawyer was convicted of forgery and executed.); Shaw, 168 Eng Rep at 142 (A letter sorter was convicted of felony theft, and although his conviction was stayed, he was kept in prison because the judges believed he might yet be convicted on other charges.); The King $v$ Sloper, 168 Eng Rep 143 (KB 1772) (A post office employee was acquitted by a jury, but the decision of the appellate court was never reported, and the defendant was kept in prison for at least five years following the acquittal.); The King $v$ Sterling, $168 \mathrm{Eng}$ Rep 152 (KB 1773) (A law clerk was convicted of forgery and sentenced to death.); The King $v$ Gascoigne, 168 Eng Rep 243 (KB 1783) (A bailiff was convicted of robbery.); The King $v$ Gastineaux, 168 Eng Rep 310 (KB 1786) (An excise officer 


\begin{tabular}{||l|c|c||}
\hline $\begin{array}{l}\text { Rule Applied } \\
\text { (implicit or explicit) }\end{array}$ & $1^{65}$ & 57 \\
\hline \% Rule Application & $13 \%$ & $52 \%$ \\
\hline
\end{tabular}

The only case in Leach in which a defendant holding a public trust received anything approaching the benefit of the Rule is The King $v$ Skutt, in which a post office letter sorter benefited from a very narrow reading of a pair of felony theft statutes. ${ }^{66}$ Even there, however, the benefit of the Rule was limited to protecting the defendant's life, rather than his liberty-he was convicted of grand larceny at common law and transported, ${ }^{67}$ a punishment as stiff as those imposed on many non-public trust defendants who did not enjoy the benefit of the Rule. ${ }^{68}$ In fact, by the time Skutt was decided, transportation was not a punishment reflecting much lenity. It had been a statutorily sanctioned alternative to capital punishment for nearly a century, and had been the preferred punishment for felonies for decades. ${ }^{69}$ Furthermore, for many convicts, transportation turned out to be a death sentence anyway. ${ }^{70}$

The Leach cases reflect the dual concerns of eighteenth-century courts that made both the Rule and the public trust exception important judicial tools. The courts were reluctant to impose unreasonably harsh penalties, but also reluctant to stretch the Rule to protect parties who had public duties-parties who held

was convicted of assault.).

6s The King $v$ Skutt, 168 Eng Rep 155 (KB 1774).

65168 Eng Rep 155, 155 (KB 1774). The statutes at issue were 5 Geo 3, ch 25, and 7 Geo 3, ch 50 .

${ }^{67}$ Skutt, 168 Eng Rep at 156. "Transportation"-the English practice of exiling, rather than executing, convicted felons-was "a suitable punishment for persons whose death sentences it was thought desirable to commute." William S. Holdsworth, II $A$ History of English Law 568, 571 (Little, Brown 1938). During the pre-Revolutionary War period covered by this survey, most transported convicts were sent to the American colonies. Later, they were sent to Australia. See id at 570-75 (describing the development and applications of transportation).

68 See case summary on file with U Chi L Rev.

69 See Hall, Theft, Law and Society at 112-13 (cited in note 12). See also Roger A. Ekirch, Bound for America: The Transportation of British Convicts to the Colonies, 1718177521 (Oxford 1987) (reporting that between 1718 and 1769, 69.5 percent of convicted felons were transported to America, 15.5 percent were hanged, and the rest were subjected to a variety of lesser punishments); Langbein, $50 \mathrm{U}$ Chi L Rev at 36-41 (cited in note 14) (discussing application of capital punishment in England).

${ }_{70}$ See Robert Hughes, The Fatal Shore 145 (Knopf 1987) (reporting mortality rates on early transports to Australia, including a death toll of almost 50 percent among convicts transported by the Second Fleet in 1790). 
public trusts as part of their work, and who could reasonably be expected to know the bounds of acceptable behavior. To see this, simply contrast Skutt's fate (transportation) with that of a majority of the other defendants who enjoyed the benefit of the Rule: of fifty-seven, forty were acquitted, discharged, or pardoned. ${ }^{\mathbf{7 1}}$

The varied social and economic circumstances of the public trust defendants indicates that their special treatment was not based on some other underlying social force or bias. The public trust defendants essentially spanned the same socioeconomic range as their neighbors who were enjoying the benefit of the Rule. They ranged from James Gibson, an attorney, ${ }^{72}$ to Thomas Hassel, a postal worker, ${ }^{73}$ to James Gastineaux, a tax collector, ${ }^{74}$ to John Sterling, a student. ${ }^{75}$ No factor discernible on the face of the cases, other than the public trust exception, provides a reasonable explanation for the relatively high standards imposed on this disparate collection of characters.

Notably, although the public trust defendants were almost always denied the benefit of the Rule, they were not denied due process as it existed at the time. For example, after losing his bid for discharge under the Rule, Thomas Hassel "put on his defence" and was acquitted. ${ }^{76}$ This supports the discussion of the fairness of the public trust exception in Part I: the function of the public trust exception is not to surprise or unfairly burden public trust defendants. Rather, the exception simply releases the courts from the constraints of the Rule and allows them to apply conventional legal reasoning to ambiguous statutes.

One slightly disconcerting footnote to the Leach survey is concealed within the public trust cases. In the two cases in which the accused were associated with the legal profession, the defendants were convicted and sentenced to death, without any expression by the courts of sensitivity to the finer points of statutory construction or the sanctity of life. ${ }^{77}$

"See case summary on file with U Chi L Rev.

72 Gibson, 168 Eng Rep at 133.

${ }^{73}$ Hassel, 168 Eng Rep at 103.

74 Gastineaux, 168 Eng Rep at 310.

75 Sterling, 168 Eng Rep at 152.

${ }^{76}$ Hassel, 168 Eng Rep at 105.

77 See Gibson, 168 Eng Rep at 134 (A lawyer, Gibson, was executed.); Sterling, 168 Eng Rep at 152-53 (A law clerk "inhabiting chambers in the [Middle] Temple," Sterling, was sentenced to death, but his ultimate destiny is not reported.). See also, William Shakespeare, Henry VI, Part II, Act IV, Scene II, in G.B. Harrison, ed, Shakespeare: The 


\section{Federal Cases, 1991-1992: Summary of Modern Results}

The results of the 1 Leach survey are paralleled closely by the results of a similar survey of modern federal cases. ${ }^{78} \mathrm{Com}-$ parisons of eighteenth-century application of the Rule to courts' use of the Rule today are, however, imperfect. Not only have values and vocabularies changed, but so has the use of the Rule. Unlike the eighteenth-century courts, which limited their explicit uses of the Rule to capital cases, modern courts apply the Rule to all sorts of criminal statutes. ${ }^{79}$ In the eighteenth century, courts rarely announced their use of the Rule, while today they announce it often. ${ }^{80}$ The treatment of public trust defendants, however, does not appear to have changed much at all, as the table below demonstrates.

(Stevens dissenting) (rejecting the Court's "apparent unawareness of the function of the independent lawyer as a guardian of our freedom").

78 Selection of the modern federal case sample was as arbitrary as it was for the Leach reporter. The objective was simply to survey a sample of recent federal cases of about the same size as the Leach sample, and to test for the same kinds of decision patterns identified in Leach. The survey consisted of decisions from 1991 and 1992 because they were the most recent years for which it is reasonably certain that final decisions had been rendered. No post-1992 decision on appeal or remand found a defect in a court's application or rejection of the Rule in the cases surveyed.

79 Courts today apply the Rule to even relatively minor crimes, see, for example, United States $v$ Herring, 933 F2d 932, 938 (11th Cir 1991) (applying the Rule to a vague statute criminalizing the sale of "black box" satellite dish unscramblers), as well as to sentencing guidelines, see, for example, United States $v$ Kinder, 946 F2d 362, 368-69 (5th Cir 1991) (applying the Rule to impose the more lenient of two possible punishments under the guidelines for career offenders), and civil statutes with criminal cognates, see, for example, United States $v$ Thompson / Center Arms Co., 504 US 505, 518 (1992) (invoking the Rule to application of the National Firearms Act, a civil statute with criminal implications). In addition, while there were dozens of cases reported by Leach in which no statute was identified, or even mentioned, for crimes charged, this is not the case for twentiethcentury criminal cases in the federal courts, since "there are no [federal] common-law offenses." United States $v$ Gradwell, 243 US 476, 485 (1917), citing United States v Hudson, 11 US (7 Cranch) 31, 32 (1812).

${ }_{80}$ It is probably unrealistic to think that they do so in every case. However, given the wide currency of the term "rule of lenity," it seems realistic to assume that they do so more often than not, and there is no particular reason to think that courts would be more likely to report applications than rejections of the Rule, or vice versa. The case survey analyzed in this Part is based on these assumptions-it uses only cases that announce their consideration of the Rule, either in the decision or in a concurrence or dissent. 
Table 2: Comparison of Rates of Rule Application in "Public Trust Cases" and "All Other Cases"

\begin{tabular}{||l|c|c|}
\hline & Public Trust Cases & All Other Cases \\
\hline Cases & 8 & 123 \\
\hline Rule Not Applied & $7^{82}$ & 81 \\
\hline Rule Applied & $1^{83}$ & 42 \\
\hline \% Rule Application & $13 \%$ & $34 \%$ \\
\hline
\end{tabular}

The results of this survey are very close to those from the Leach survey in all categories save one: the number of cases in which courts declined to apply the Rule when the defendant did not hold a public trust increased significantly. ${ }^{84}$ While this re-

81 The cases reported in this table are criminal cases reported in the 1991 and 1992 volumes of the United States Reports (volumes 498-504), Federal Reporter, Second Series (volumes 919-83), and Federal Supplement (volumes 751-818), plus a few available only from on-line services, in which the Rule was relevant and explicitly addressed. A table of cases is on file with $U$ Chi $L$ Rev. Where more than one court heard a case and discussed the Rule, only the highest court's opinion is included in the study.

${ }_{82}$ Evans v United States, 504 US 255, 271 n 23 (1992) (rejecting "the dissent's narrow view," which included application of the Rule in a Hobbs Act case against a county commissioner); United States $v$ Newman, 982 F2d 665, 673-74 (1st Cir 1992) (acknowledging the rule, but not applying it to the sentence of a correctional officer convicted of assaulting a prisoner); United States $v$ Samalot-Perez, 1991 US App LEXIS 21191, *8 (1st Cir) (refusing to apply the Rule to multiple sentences of police officer convicted of conspiracy to commit a diamond robbery); United States v Contreras, 950 F2d 232, 243-44 (5th Cir 1991) (rejecting Rule application to police officer's appeal of criminal civil-rights violations); United States v Cicco, 938 F2d 441, 442-46 (3d Cir 1991) (rejecting trial court's application of the Rule, acquitting defendants on other grounds, and noting unappealed convictions on other counts of the underlying prosecution); United States $v$ Schaltenbrand, 930 F2d 1554, 1560 (11th Cir 1991) (rejecting application of the Rule to former military officer's appeal of conflict-of-interest conviction); United States v Lipari, 1992 US Dist LEXIS 9929, *19 \& n 3 (D NJ) (refusing to apply the Rule to corruption charges against a suburban mayor).

${ }^{83}$ United States $v$ Coiro, 922 F2d 1008, 1014-15, 1018 (2d Cir 1991) (applying the Rule to eliminate conviction on one of two identical counts against an attorney, but not reducing the identical, concurrent sentence on the remaining conviction).

s4 This may be a result of a modern selection effect not applicable in the eighteenth century. For example, since many criminal defendants receive free legal representation today that they would not have received two hundred years ago, they may have more opportunities to fight prosecution, rather than bargaining with the prosecutor or fleeing. As a result, there are probably more defenses, and therefore more Rule claims raised in cases that would not even have made it onto a docket in the eighteenth century. Also, in an age of word processing and electronic forms, the Rule may be coming up in more cases in which it has no application. Or perhaps courts are not as quick to apply the Rule in an 
sults in a reduced ratio of applications to nonapplications of the Rule in conventional criminal cases, it does not affect the basic argument: on a percentage basis, many more conventional defendants than public trust defendants enjoy the benefit of the Rule (four times as many in the eighteenth century and almost three times as many today ${ }^{85}$ ). Although conventional defendants may benefit less from the Rule today than they did two hundred years ago, the fact that public trust defendants stand about the same chance of benefiting from the Rule today as they did two hundred years ago is an important indicator of the staying power of the public trust exception. I make no claim of statistical significance for these numbers, only a claim that such a striking disparity of treatment under the Rule between public trust defendants and all others calls for some explanation, ${ }^{86}$ and that the public trust exception explains them in a way that is consistent with the modern rationales for the Rule itself.

Modern American public trust defendants have the same general experiences and characteristics as the parties reported on by Leach. Again, as in the Leach cases, the unusual public trust defendant who nominally enjoyed the benefit of the Rule proves the public trust exception, since he does not really benefit from the Rule. Just as Timothy Skutt received the benefit of the Rule

environment with very little capital punishment. On the other hand, it seems reasonable to expect that the parties to criminal proceedings would adjust their behavior to accommodate new developments. See generally George L. Priest and Benjamin Klein, The Selection of Disputes for Litigation, $13 \mathrm{~J}$ Legal Stud 1 (1984) (theorizing that litigants develop rational estimates of the likelihood of their success or failure in court, and base their decisions to proceed or settle partially on that basis). But see William M. Landes and Richard A. Posner, Adjudication as a Private Good, 8 J Legal Stud 235, 259-84 (1979) (arguing that Priest's equilibrium model of litigation "overstate[s] the tendency of a common law system to produce efficient rules").

85 Compare "\% Rule Application" totals in Tables 1 and 2.

${ }^{86}$ Setting aside concerns about selection bias and debatable case analysis, a basic "chi-square test" of the data summarized in the two tables in this Comment shows high statistical confidence for the eighteenth-century English data (less than 4 percent chance that the data is a statistical fluke), lower confidence for the modern data (about one-in-five chance that the data is a statistical fluke), and very high confidence in the combined data (less than 2 percent chance of a fluke). See Joan Welkowitz, Robert B. Ewen and Jacob Cohen, Introductory Statistics for the Behavioral Sciences 281-96 (Harcourt Brace Jovanovich 3d ed 1988) for an introduction to chi-square analysis. Note that the third test rests on an assumption that there is no meaningful difference between the two sets of data. The low statistical confidence in the modern number results from the lower percentage of applications of the Rule in non-public-trust exception cases, making an explanation of that change an important factor in determining the statistical significance of the modern data. Such a study is beyond the scope of this Comment. Documentation of the test methodology and results are on file with U Chi L Rev. 
but was transported to colonial America anyway, ${ }^{87}$ Michael Coiro received the benefit of the Rule, but the only result was that he had to serve a single sentence rather than two identical, concurrent sentences for obstruction of justice ${ }^{88}-a$ virtually meaningless change.

The demographic characteristics of the modern public trust defendants are diverse, as they were in the Leach cases, ranging from Eugene Schaltenbrand, a former Air Force Colonel, ${ }^{89}$ to John Evans, a county commissioner, ${ }^{90}$ to Michael Newman, a prison guard. ${ }^{91}$

In sum, between public trust defendants in the mid-eighteenth century and the late-twentieth century, the similarities are numerous and the differences are minimal, at least for the purpose of evaluating the vitality and durability of the public trust exception. And there is no indication that the public trust exception is waning.

The surveyed case law of eighteenth-century England and twentieth-century America both reinforces conventional wisdom about the existence, lineage, and function of the Rule, and reveals an unconventional limit on the Rule-the public trust exception. While large percentages of criminal defendants in both periods have enjoyed the benefit of the Rule (narrow construction of criminal statutes in favor of the accused), those accused of violating their public trusts almost never have. Not only does the public trust exception approach provide the only consistent explanation for the misfortunes of such an otherwise diverse group of defendants, it also comports with the quasi-constitutional norms underlying the Rule itself.

\section{QUASI-CONSTITUTIONAL NORMS AND QUESTIONABLE CONSEQUENCES}

Two quasi-constitutional norms provide the primary modern rationales for the Rule. ${ }^{92}$ They are straightforward: (1) protec-

${ }^{87}$ Skutt, 168 Eng Rep at 156.

${ }^{88}$ Coiro, 922 F2d at 1015-18 (using the Rule to dismiss one count, but declining to resentence "since the prison sentences on Counts Seven and Eight are concurrent and no fine was imposed on either count").

Schaltenbrand, $930 \mathrm{~F} 2 \mathrm{~d}$ at 1556.

so Evans, 504 US at 257.

91 Newman, 982 F2d at 667.

92 The distinction between the quasi-constitutional norms driving the Rule and the truly constitutional standards of due process and separation of powers is more than a technicality. Whether a statute violates constitutional requirements or quasi-constitution- 
tion of the due process right to fair notice of the extent of the criminal law $^{93}$ and (2) preservation of the separation-of-powers principle that the definition of behavior to be proscribed by the community is the exclusive province of the legislature. ${ }^{94}$ They set out intermediate standards between the all-or-nothing battle of constitutional judicial review ${ }^{95}$ and the void-for-vagueness doctrine ${ }^{96}$ on the one hand, and multifactor balancing tests on the other. ${ }^{97}$ As a mechanism for fairly aligning public trusts with accountability and minimizing demands on judges to test the limits of statutory construction of criminal statutes, the public trust exception fits comfortably within both the fair notice and the separation of powers rationales for the Rule.

This Part does two things. First, it locates the public trust exception within the two rationales for the Rule. After posing a hypothetical situation in which the public trust exception is applied in a manner that appears to undermine the rationales, it demonstrates the soundness of the exception via counter-arguments from the two rationales. Second, this Part poses and answers two of the stronger objections to the public trust exception.

al ones can determine whether the statute lives or dies. For example, a statute that a court concludes is "void for vagueness" under the constitutional standard is, obviously, void, see, for example, United States $v$ Cohen Grocery Co., 255 US 81, 87-93 (1921), while a statute that a court concludes is ambiguous but capable of supporting a narrow construction under the Rule survives. See, for example, United States $v$ Bass, 404 US 336, 338, 347-51 (1971), in which the Court ensured the constitutionality of a gun control statute by adopting a narrow construction. The courts, however, have not drawn a sharp line between the two, and they "may most usefully be thought of as contiguous segments of the same spectrum." Herbert L. Packer, The Limits of the Criminal Sanction 93 (Stanford 1968). See also United States v Biocic, 928 F2d 112, 114 (4th Cir 1991).

${ }_{93}$ United States $v$ Singleton, 946 F2d 23, 24 (5th Cir 1991) (The Rule is designed to ensure that "members of an innocent citizenry are not surprised by being prosecuted for acts that they could not know were criminal.").

94 Bass, 404 US 336, 348 (1971) ("[B]ecause of the seriousness of criminal penalties, and because criminal punishment usually represents the moral condemnation of the community, legislatures and not courts should define criminal activity.").

${ }_{95}$ See Marbury v Madison, 5 US (1 Cranch) 137, 180 (1803) ("[A] law repugnant to the constitution is void.").

${ }_{96}$ See, for example, Connally v General Construction Co., 269 US 385, 391 (1926) (" $[A]$ statute which either forbids or requires the doing of an act in terms so vague that men of common intelligence must necessarily guess at its meaning and differ as to its application, violates the first essential of due process of law."). See also Jeffries, $71 \mathrm{Va} \mathrm{L}$ Rev at 189, 196-97 (cited in note 27) (describing the doctrine and its current status); Anthony G. Amsterdam, Note, The Void-for-Vagueness Doctrine in the Supreme Court, 109 U Pa L Rev 67, 67-75 (1960) (summarizing cases).

${ }_{97}$ See Antonin Scalia, The Rule of Law as a Law of Rules, $56 \mathrm{U}$ Chi L Rev 1175, 1182 (1989) (describing a judge applying a balancing test as "resembl[ing] a finder of fact more than a determiner of law"). 


\section{A. Counter-Arguments: Quasi-Constitutional Norms}

At first blush, the public trust exception may look like a terrible infringement on the principles of due process (preserving fair notice) and separation of powers (preventing judicial lawmaking) that the Rule is supposed to protect. Consider the following scenario:

Congress and the President enact a statute governing the ethical obligations of government workers and the relations between private parties and government workers. The statute includes an ambiguous partial ban on gifts between lobbyists and government employees.

Soon thereafter, L, a lobbyist, makes a gift to G, a government official with whom she is friendly. G, in turn, makes a gift to $L$, also as a gesture of friendship. The gifts could reasonably be viewed as either legal or illegal under the ambiguous statute. A law enforcement officer uncovers the gift exchange, and prosecutions follow.

At trial, the court identifies two reasonable interpretations of the ambiguous statute, one quite narrow and the other broader. The court invokes the Rule, holds that under the narrow interpretation L's giving of a gift to $G$ and L's acceptance of a gift from $G$ were not illegal, and dismisses the charge against $L$. However, the court also holds that the broader reading of the statute is the most reasonable, and that under the broader reading, G's acceptance of L's gift was illegal. The prosecution of hapless G goes forward. ${ }^{98}$

\section{Counter-argument \#1: Due process and fair notice.}

On what basis can the public trust exception, as applied in the scenario above, possibly be consistent with the Rule's protection of G's right to fair notice of the criminality of his acts? After all, it is obvious from the court's own holdings that there is more than one reasonable interpretation of the statute. A gift exchange is the epitome of a reciprocal relationship, and it would seem to follow that both participants should be punished equally. Instead, the consequence of the public trust exception in this scenario is 
sharply disparate treatment by the court: releasing one party and prosecuting another.

In fact, this scenario is unproblematic so long as the broader construction of the statute developed by the court, and applied to $\mathrm{G}$, is the most reasonable interpretation. In that case, the court is not holding $\mathrm{G}$ to an unreasonably high standard or stretching the statute beyond reason, but neither is it protecting irresponsible or strategic behavior by a party holding a public trust. G should not be surprised by the prosecution since, if he had read the statute in a reasonable way, he would have had fair notice.

This approach does not presume that reasonable interpretations are easy to arrive at, or that all reasonable people will or must arrive at identical interpretations. Instead, it supposes that holders of public trusts are interested in, and sensitive to, the community values and standards that generally define "reasonableness." Further, to the extent that the holder of a public trust may have some uncertainty about the legality of his behavior in the course of his public duties, the resulting "chilling effect" will be of little cost to him and at least some small benefit to the community he serves. ${ }^{99}$

Were a court to endorse the argument that a party holding a public trust has no more of a duty to know and abide by the laws governing his trust than the average citizen, it would be inviting a party holding a public trust to act as though he did not hold the trust. It would be inviting irresponsible and strategic behavior. Conceptually and practically, accepting a public trust is itself a form of constructive notice.

The main problem with an outraged response to the scenario above is that it ignores the importance of G's status as an agent for the public and his associated duties and public trust. It conflates two different expressions of the rule of law: the equality principle that all citizens are equal under the law, and the equity principle that similarly situated parties should be treated similarly. ${ }^{100}$ In this scenario, $L$ and $G$ are not similarly situated because G's status, relative to the public and relative to the statute that governs his behavior as a public agent, practically requires the differential treatment by the court.

See text accompanying notes 103 and 117.

100 See, for example, Rostker $v$ Goldberg, 453 US 57, 79 (1981) ("The Constitution requires that Congress treat similarly situated persons similarly, not that it engage in gestures of superficial equality."). 
This sort of recognition of the public trust that agents of the public owe to their communities should serve to reinforce rather than undermine due process functions in general, and fair notice in particular, because it makes a fair match between expected levels of knowledge and effective notice. In the fair notice context, this should be especially relevant to public choice concerns about strategic behavior by lawmakers.

A public choice theorist, concerned about congressional awareness of the Rule, might offer a model of the following sort. ${ }^{101}$ If a legislator knows that her constituents want a safe society and honest government, and will punish at the polls legislators who fail to pass laws criminalizing the relevant reprehensible behavior, then she will work to enact laws criminalizing such behavior. But if she also knows that rhetorically forceful but legally ambiguous penal statutes will satisfy constituent demands while diverting difficult and potentially unpopular policy and budgetary decisions to other institutional players in the executive branch and local governments, she may well be inclined to support ambiguous laws, thereby satisfying voter demands without substantially increasing her own accountability. ${ }^{102}$

Adding the public trust exception to the above model would answer the public choice theorist's concern about accountability: if Congress also knows that courts will not apply the Rule when the defendant holds a public trust, then the congressional incentive turns 180 degrees (or at least a lot)—supporting enactment of less ambiguous criminal statutes, at least those that might touch on a public trust. Why? Because the cost of ambiguity is no longer borne entirely by society; it is now borne at least in part by the legislator herself, who is exposed to reasonable, rather than narrow, interpretations of her vague penal statutes.

Assuming the obvious, that her electorate will reject the elimination of criminal statutes that might touch on a legislator's public trust obligations, the legislator has two basic alternatives: (a) she can stick with reliable old ambiguity and hope that in the unhappy event of a prosecution involving a public trust, a court will either mistakenly apply the Rule or apply the public trust exception with a view of reasonableness that is no more rigorous

${ }^{101}$ This model is short and illustrative. It does not cover every facet of public choice and the public trust exception-only the high points. For a summary of public choice theory and a survey of the literature, see Daniel A. Farber and Philip P. Frickey, The Jurisprudence of Public Choice, 65 Tex L Rev 873 (1987).

102 See note 5 and accompanying text. 
than hers, or (b) she can enact criminal statutes that set the clearest possible standards, accept the burden of comporting her behavior to those standards, and rest relatively easy in the knowledge that her acts within those standards will not be criminal under the Rule and the exception.

Although at first blush, option (a) may look like a better choice, it is not. If she wants the same level of stay-out-of-jail confidence as she would have under either a Rule-without-exception regime or option (b), the legislator must take full account of the "chilling effect" of the most demanding judge or jury she might encounter. This "chill," which may or may not be a higher standard than her own personal standards, will almost certainly be higher than the standards established under option (b), and is, in any event, beyond the control of a legislator who presumably wants to retain as much influence as possible over her personal and political destinies. Balance the electoral value of option (a), with its righteous but vague penal statutes that put bad people away for long stretches, ${ }^{103}$ against option (b), with its (perhaps) reduced electoral value of clear, restrained criminal statutes, plus the security of relatively clear bounds of liability, plus the fact that in most jurisdictions a criminal conviction is a significant liability for a politician. Some movement toward option (b) seems to make sense for the politician who wants to win again, and who is also fond of her own liberty.

Ironically, this reaction to the public trust exception would also reduce the need for the Rule itself, since an increase in clear legislation would result in fewer occasions for courts to construe ambiguous statutes. So, under the due process basis for the Rule, the public trust exception should be appealing both to supporters of the Rule, who should be pleased that the exception is consistent with the Rule itself, and to opponents of the Rule, since the exception should reduce the incidence of the Rule's application. ${ }^{104}$

${ }^{103}$ See, for example, the federal mail fraud statute, 18 USC § 1341 (1994).

104 The notion of notice based on public trust status and a corresponding duty to know the law related to the public trust is not the same as an argument that sophisticated parties should be held accountable for knowledge of the law, or an even more general argument that all citizens should be held accountable for reasonable constructions of even ambiguous laws. The former is connected to an objective role from which an individual can withdraw if she wants to. The "sophistication" and "citizen" arguments are connected to more nearly constitutive characteristics of the individual, and in some cases to more subjective roles. Extending an exception to the Rule beyond the public trust context on a notice rationale would be much less clear cut, and therefore much more difficult to manage from the courtroom and much more likely to undermine the second quasi-constitu- 
2. Counter-argument \#2: Separation of powers and prevention of judicial creation of criminal law.

Consider again the scenario laid out at the beginning of this Part. Again, the initial reaction of a reader might be to object: the court is usurping a legislative function. The court appears to be creating two laws-one for $L$ and one for $G$-where Congress has passed only one. Like the fair notice problem, however, this situation is, when analyzed in terms of the roles and duties of the parties, unproblematic.

Bear in mind that both the Rule and the public trust exception are already "law" in their own right, and have been for centuries. ${ }^{105}$ So, at a very general level, the scenario above should be of no concern at all, since it merely reflects the application of an established common law canon of construction.

More specifically, the court's creation of two different "laws" for two different parties is no different from other practices in criminal law in general. Two parties to an illegal act are frequently treated differently. Consider statutory rape, ${ }^{106}$ for example, or the distinct positions of prostitute and pimp under the Mann Act, ${ }^{107}$ or the different duties of care that parents, as opposed to strangers, owe to children, or the duties that other parties owe to dependents in their care. ${ }^{108}$ Consider also the duty

tional rationale for the Rule-separation of powers.

This concern does not necessarily mean that courts have not considered the merits of an exception to the Rule based on the sophistication of the defendant. See text accompanying notes 131-32 for an example that could be status or sophistication based. For an example of a sophisticated eighteenth-century criminal defendant who did not get the benefit of the Rule, see The King $v$ Doctor Dodd, 168 Eng Rep 180 (KB 1777), one of the most famous cases of its time. See also George Birkbeck Hill, 3 Boswell's Life of Johnson 158-68 (Bigelow, Brown 1921) (detailing Johnson's role in the Dodd case).

${ }_{105}$ See, for example Tarpley $v$ Dugger, 841 F2d 359, 364 (11th Cir 1988) ("This rule of lenity [is] a part of our common law.") (citations omitted).

${ }_{106}$ See, for example, The Queen $v$ Tyrrell, 1 QB 710, 711 (1893) (holding that a minor cannot be convicted of aiding a statutory rape on herself because the statute was designed only for her protection).

${ }_{107} 18$ USC \& 2421 (1994). See, for example, Gebardi $v$ United States:

We place [the harsher treatment of pimp than prostitute] rather upon the ground that we perceive in the failure of the Mann Act to condemn the woman's participation in those transportations which are effected with her mere consent, evidence of an affirmative legislative policy to leave her acquiescence unpunished.

287 US 112, 123 (1932).

${ }^{108}$ See Sanford H. Kadish and Stephen J. Schulhofer, Criminal Law and Its Processes: Cases and Materials 181-203 (Little, Brown 6th ed 1995) (discussing cases testing the limits of the duty of care). 
owed by corporate officers to their customers under the Federal Food, Drug, and Cosmetic Act: ${ }^{109}$

The requirements of foresight and vigilance imposed on responsible corporate agents are beyond question demanding, and perhaps onerous, but they are no more stringent than the public has a right to expect of those who voluntarily assume positions of authority in business enterprises whose services and products affect the health and well-being of the public that supports them. ${ }^{110}$

It is a duty that assigns to officers a different, more accountable status than their employees whose acts or omissions result in criminal liability. ${ }^{111}$ The Federal Sentencing Guidelines even provide for enhancement of criminal penalties when a defendant abuses a position of public (or private) trust. ${ }^{12}$ Disparate treatment under the criminal law based on the status of the defendant is commonplace.

Furthermore, when a court applies the most reasonable construction of an ambiguous criminal statute rather than a narrower construction, it is following more nearly the presumed intent of a reasonable legislature, ${ }^{113}$ thereby minimizing, rather than exacerbating, concerns about judicial usurpation of the lawmaking function. Application of the Rule, on the other hand, calls for more discretion, and even speculation, on the part of judges who must identify the reasonable degree of narrowness required to protect the constitutional rights of the defendant without making hash out of the statute in question. ${ }^{114}$ Conceptually and practically, accepting a public trust means accepting some of that in-

10921 USC \$§ 301 et seq (1994).

11 United States v Park, 421 US 658, 672 (1975).

11 Id at 670-71.

112 Federal Sentencing Guidelines, 18 USCA § 3B1.3 (West 1996) ("If the defendant abused a position of public or private trust ... in a manner that significantly facilitated the commission or concealment of the offense, increase [punishment] by 2 levels.").

${ }^{113}$ See Henry M. Hart, Jr. and Albert M. Sacks, The Legal Process: Basic Problems in the Making and Application of Law 1378 (Foundation 1994) (William N. Eskridge, Jr. and Philip P. Frickey, eds) (stating that courts should interpret statutes as if the enacting legislature "was made up of reasonable persons pursuing reasonable goals reasonably"). See also Heydon's Case, 76 Eng Rep 637, 638 (KB 1584) ("[T] always to make such construction as shall suppress the mischief ... and to add force and life to the cure and remedy, according to the true intent of the makers of the Act.").

114 See, for example, Williams $v$ United States, 458 US 279, 290 (1982), in which the Court applied the Rule and overturned a conviction for check-kiting under 18 USC § 1014 (1976). 
terpretive responsibility, and being held accountable for exercising it.

When a court appropriately forgoes application of the Rule based on the public trust exception, as the court did in the scenario above, it is not creating law. It is simply applying the law differently to different parties, based on relevant and valid status distinctions-an approach widely accepted in criminal law and supported by the quasi-constitutional norms behind the Rule itself.

\section{B. Questionable Consequences}

The public trust exception is subject to many of the same objections as the Rule itself. Its own existence, after all, depends on the existence of the Rule. In addition, however, the exception is subject to at least two other substantial and reasonable concerns. First, a skeptic might ask whether the addition of another canon of construction can really serve to clarify and legitimize the Rule, or whether it will simply add yet another unpredictable wrinkle to the law. Second, the public trust exception can be viewed as a burden, deterring worthy people from accepting public trusts that they might accept if they could count on the protection of the Rule.

\section{Another canon?}

The short answer to the first objection is that the public trust exception is not a canon, it is an anticanon. The function of the exception is to preclude application of the Rule-itself a canon requiring courts to move away, at least in some cases, from the most reasonable interpretations of statutes-in contexts where such application is inappropriate. In so doing, the exception offers courts more opportunities to simply construe statutes reasonably. To the extent that the public trust exception interferes with the workings of the law, it does so to reduce the incidence of relatively narrow and unbalanced interpretations of statutes and to increase the incidence of reasonable, balanced constructions.

Furthermore, open acknowledgment and explanation of the public trust exception may well serve to reduce confusion in criminal law. To the degree that it helps to explain the "notoriously 
sporadic" application of the Rule, ${ }^{115}$ the exception can only serve to facilitate, rather than inhibit, understanding of the law and of particular decisions. Perhaps some of the arbitrariness of the Rule is a result of an incomplete definition of the Rule in the legal record. If so, announcement of the public trust exception, along with any other qualifications to the Rule, might result in a less arbitrary Rule.

Perhaps most fundamentally, failure to publicize the public trust exception is a disservice to the public in its own right. Arguably, an unfair notice problem exists now, since the public trust exception is operating without explicit notice to the citizens who are subject to it. Since at least the eighteenth century, courts have been denying the holders of public trusts the benefits of the Rule, yet no court has ever explicitly stated that it is applying a settled exception. Unannounced application of the public trust exception is contrary to the due process principle behind the Rule itself.

\section{Driving away good people?}

The second concern might be phrased as follows: We should not retain, or at least we should not publicize, the public trust exception because it will raise the price of public service even higher than it already is, discouraging otherwise well qualified candidates from campaigning, applying, or volunteering for service. They will be deterred by fear that, without the benefit of the Rule, they will be trapped in the teeth of ambiguous criminal statutes. After all, when the risks associated with service rise, so does reluctance to serve. ${ }^{116}$

On the other hand, the function of the public trust exception is to apply the most reasonable construction of a statute to the accused holder of a public trust. Perhaps the community should be leery of a prospective public servant who is reluctant to be held to a reasonable standard of behavior. While some sensitivity to perceived reductions in legal protection for holders of public

115 Kahan, $1994 \mathrm{~S}$ Ct Rev at 346 (cited in note 4).

${ }^{116}$ See, for example, Amanda Bennett, Losing Ground? Surveyed Firms Report Fewer Women Directors, Wall St J 17 (July 17, 1987), reporting that "more people are turning down board seats and citing fear of legal liability as the reason," and that fear of liability as a factor among those declining board seats rose from 2.5 percent in 1985 to 14.2 percent in 1987; Cathy Trost, Labor Letter: A Special News Report on People and Their Jobs in Offices, Fields and Factories, Wall St J 1 (Mar 24, 1987), reporting that some directors resigned from Lear Petroleum Corporation when the firm lost its liability insurance. 
trusts is certainly called for, communities should be pleased to be free of public servants who cannot tell the difference between a kickback and a cup of coffee, and, a fortiori, those who can tell the difference, but choose to ignore it. ${ }^{117}$ Finally, the increased cost of operating under the public trust exception is almost certainly minimal for those not actively seeking to abuse the law. Public servants know they are under a lot of scrutiny anyway and a little extra "chilling effect" may not be a bad thing.

\section{The PUblic TRUST EXCEPTION IN ACTION: THE MCNALLY STORY}

Certainly, not every public trust criminal case follows the public trust exception story told in the first four Parts of this Comment. The most prominent recent case in which the exception was ignored is McNally $v$ United States. ${ }^{118}$ The full story of McNally, however, can be credibly read as one episode in the continuing saga of the survival of the unspoken public trust exception. The McNally story supports the existence of the exception because it reveals latent congressional, judicial, and executive reluctance to allow the Rule to be used to relieve parties holding public trusts of the reasonable expectations of the community and the law.

The Supreme Court's decision in McNally, viewed by itself, undermines the thesis of this Comment. James E. Gray, a Kentucky politician, and Charles J. McNally, a front man for Gray, ran an elaborate workers' compensation insurance kickback scheme, but they were caught and convicted of conspiracy to defraud and mail fraud. ${ }^{119}$ The convictions were based on a theory of fiduciary duty to the public, the breach of which consti-

117 See, for example, United States v O'Grady, 742 F2d 682, 684-85, 694 (2d Cir 1984) (applying the Rule in an extortion case involving public transportation official who accepted tens of thousands of dollars worth of travel and entertainment from a vendor "despite having instructed his subordinates not to accept anything."). See also Ethics in Government Act, 18 USCA $§ \S 203,216$ (West 1989 \& Supp 1995).

118 483 US 350.

11 United States $v$ Gray, 790 F2d 1290, 1292-93 (6th Cir 1986), rev'd as McNally, 483 US 350. Gray and McNally were well connected, but not particularly highly placed, figures. Recall, however, that public trusts are not limited to high-ranking political figures, see, for example, United States $v$ Ajiboye, 961 F2d 892, 895 (9th Cir 1992) (Postal Service mail carrier held a public trust to deliver the mail.); United States $v$ Williamson, 53 F3d 1500, 1525 (10th Cir), cert denied as Dryden v United States, 116 S Ct 218 (1995) (Traffic officer held a public trust to hold confidential information about drug conspiracy investigations.), or to parties employed directly by the government, see, for example, Dixson, 465 US at 484,491, 496-97 (Officers of a private, nonprofit organization administering federal housing grants were "public officials" holding a "public trust."). 
tutes fraud. ${ }^{120}$ After an extensive survey of precedent and legislative history, the Supreme Court acknowledged that: "We believe that Congress' intent in passing the mail fraud statute was to prevent the use of the mails in furtherance of such schemes [as the McNally-Gray workers' compensation insurance scam]." ${ }^{212}$ The Court went on, however, to apply the Rule and reverse the convictions, explaining that Congress had not made sufficiently clear the extension of the fraud statute from traditional property and other material interests to intangible interests like the one at issue in the case-the right to honest government services. ${ }^{122}$ In other words, the Court, confronted with at least one public trust defendant (Gray), first identified the most reasonable interpretation of the statute in question, and then rejected it in favor of a narrower interpretation that released Gray from accountability for his violation of a public trust. ${ }^{123}$

Reactions in all three branches of the federal government showed that even if no one spoke explicitly of a "public trust exception" to the Rule, a broad range of public officials knew that some important conception of public duty and criminality had been violated by the Court when it applied the Rule to the federal mail fraud statute in a way that read McNally and Gray to be anything other than guilty. The decision created a cascade of motions to vacate ${ }^{124}$ because, before McNally, all twelve circuits had endorsed the "honest government services" theory rejected by the Court. At least one circuit court resisted the McNally decision, recharacterizing and then affirming an honest services conviction. ${ }^{225}$ The Justice Department pressured federal courts to

120 Gray, 790 F2d at 1294-97 (applying the mail fraud statute to both Gray, the public servant, and McNally, the entrepreneur, on the theory that "serving in public office should not be a rigid prerequisite to impressing a fiduciary duty upon individuals closely aligned with governmental activities").

${ }^{121}$ McNally, 483 US at 359.

${ }^{222}$ Id at 352, 356-60.

123 As one commentary put it: "A public official directing government contracts to a buddy in return for extensive kickbacks (the facts of McNally) knows that the conduct is fraudulent and cannot claim 'surprise' that a statute aimed at fraud might be applied to such conduct." William N. Eskridge, Jr. and Philip P. Frickey, Statutory Interpretation as Practical Reasoning, 42 Stan L Rev 321, 369 (1990).

124 See, for example, Ward $v$ United States, 845 F2d 1459 (7th Cir 1988) (vacating mail fraud conviction and discussing similar cases from other circuits). For examples of courts' responses to initial motions to vacate, see Moreno $v$ Story, 694 F Supp 1557 (S D Fla 1988); United States $v$ Walgren, 695 F Supp 495 (W D Wash 1988); United States $v$ Patterson, 690 F Supp 647 (N D Ill 1988); United States v Brennan, 685 F Supp 883 (E D NY 1988); United States $v$ Case, 684 F Supp 109 (D NJ 1988).

125 United States v Perholtz, 842 F2d 343, 365-67 (DC Cir 1988). 
construe the McNally decision very narrowly. ${ }^{126}$ Finally, the decision generated a wave of support in Congress for statutory overruling. ${ }^{127}$ Congress acted swiftly. It passed the "McNally fix" the following year. ${ }^{128}$ In short order, all three branches of the federal government were criticizing, undermining, rejecting, and overruling the McNally decision.

The Court's next opportunity to address a public trust case with the potential for Rule application came in Evans $v$ United States, ${ }^{129}$ a Hobbs Act case in which a county commissioner was convicted for taking a $\$ 7,000$ bribe to push through a rezoning request. The Court upheld the conviction. A plurality rejected the dissenters' call to apply the Rule, which relied in part on McNally's misapplication of the Rule. ${ }^{130}$

In less than five years, then, the McNally decision was statutorily overruled by Congress and its failure to apply the public trust exception was practically, albeit implicitly, rejected by the Court in Evans. These sharp, quick reversals, combined with the multibranch outcry in the wake of the McNally decision, show that McNally was an anomaly, despite its reasoned application of the Rule, because the Court bypassed the public trust exception. The Evans decision, set against its McNally background, is an indicator of the continued vitality of the public trust exception.

In his McNally dissent, Justice Stevens, joined by Justice O'Connor, argued for what was, in effect, an extended version of the public trust exception. Recognizing both the inapplicability of the Rule in a public trust context and the unacceptable practical consequences of such an application, he wrote, "[s]urely these petitioners knew that it would be unlawful to place Kentucky's insurance coverage with an agent who would secretly make hundreds of thousands of dollars available for the private use of petitioners, their relatives, and their paramours. This is, indeed,

126 Ward, 845 F2d at 1460.

${ }^{127}$ See, for example, HR 3050, 100th Cong, 1st Sess (July 29, 1987), in 133 Cong Rec H6802 (July 29, 1987) (a bill introduced by Representative Kweisi Mfume to overrule MaNally); HR 3089, 100th Cong, 1st Sess (Aug 4, 1987), in 133 Cong Rec H7078 (Aug 4, 1987) (a bill introduced by Representative John Conyers to overrule McNally, by redefining "fraud" throughout the United States Code). See also Craig M. Bradley, Foreword: Mail Fraud After McNally and Carpenter: The Essence of Fraud, $79 \mathrm{~J}$ Crim L \& Criminol $573,618-22$ (1988) (discussing legislative and executive responses to $\mathrm{McNally}$ ).

${ }_{128}$ Pub L No 100-590, 102 Stat 4508 (1988), codified at 18 USC $\S 1346$ (1994) ("For purposes of this chapter, the term 'scheme or artifice to defraud' includes a scheme or artifice to deprive another of the intangible right of honest services.").

129504 US 255 (1992).

${ }^{130}$ Id at 289 (Thomas dissenting). 
a strange application of the doctrine of lenity." 131 He then reasoned that sophisticated parties, who should know better than to violate a public trust, should be held to a reasonable, rather than a narrow, standard:

When considering how much weight to accord to the doctrine of lenity, it is appropriate to identify the class of litigants that will benefit from the Court's ruling today. They are not uneducated, or even average, citizens. They are the most sophisticated practitioners of the art of government among us. There is an element of fiction in the presumption that every citizen is charged with a responsibility to know what the law is. But the array of government executives, judges, and legislators who have been accused, and convicted, of mail fraud under the well-settled construction of the statute that the Court renounces today are people who unquestionably knew that their conduct was unlawful. ${ }^{132}$

While Justice Stevens couches his comment in terms of sophisticated parties, his exemplars are all well within the reach of the public trust exception-people with broad and important public trust duties. He did not state the exception per se, but his dissent can be interpreted as an argument in support of it. And with congressional enactment of the "McNally fix," Justice Stevens's dissent was vindicated, as was the public trust exception.

\section{CONCLUSION}

This Comment has shown that in order to conform to historic and contemporary judicial practice, the rule of lenity should be modified to read as follows:

Rule: A court confronting an ambiguous penal statute must construe it strictly in order to (a) protect the right of those covered by the law to fair notice of the criminal law, and (b) preserve the role of the legislature as the institution that defines the acts that the community condemns.

Exception: The Rule applies as stated above except when the accused holds a public trust and is charged with violating a statute relating to that trust. In that case, a court must 
apply the most reasonable interpretation of the statute, rather than a narrower one, in order to (a) protect the right of those covered by the law to fair notice of the criminal law, (b) preserve the role of the legislature as the institution that defines the acts that the community condemns, and (c) protect the public from strategic or irresponsible behavior by defendants holding public trusts.

This version of the Rule does not violate the due process rights of a public trust defendant-it does not impose a surprising construction of a statute on her. Rather, it holds her to the most reasonable standard of behavior under an ambiguous statute. It does, however, deny her the benefit of the Rule. But the Rule is no more than a defense that protects parties who might otherwise be surprised by the application of a statute to them. The public trust defendant simply "cannot claim that he [is] an innocent citizen 'surprised by being prosecuted for acts that [he] could not know were criminal."'133

Nor does this version of the Rule encourage judicial usurpation of the legislative power. In fact, it reduces the occasions courts will be called on to identify narrow, rather than the most reasonable, interpretations of ambiguous penal statutes. Assuming that legislatures are reasonable, or that at least they should be treated that way, the emphasis under the public trust exception on reaching the most reasonable interpretation facilitates judicial construction of statutes in accordance with the intent of the legislature.

Finally, this version of the Rule does not create new law. It merely articulates a centuries-old feature of established common law about which all citizens, and especially those holding public trusts, should know. Its existence is evident in the decisions of the courts that established the Rule, and in the decisions of the courts applying the Rule today.

In sum, this version of the Rule comports with the underlying quasi-constitutional bases for the Rule-due process and separation of powers-by preserving access to the Rule for only those who merit its protection and by minimizing the occasions the courts will be called on to narrow legislative enactments out of deference to the dictates of an unenacted canon of construction. Moreover, if publicized, this version of the Rule will help to 
resolve the policy concerns outlined in the introduction to this Comment: (1) it will foster better, more consistent adjudication, by forestalling problems like the McNally imbroglio; (2) it will put the exception in the legal record, where all law belongs; (3) it will enhance the credibility of the Rule by putting an understandable and reasonable limit on it; (4) it will resolve any doubts about fair notice to public trust defendants; and (5) it will encourage legislators to pass clear, understandable, reasonable criminal laws, for their own protection, if nothing else.

The Rule may or may not merit a permanent home in American law, but for now, it is with us. As long as it is, we should be clear about what it does and does not do, who it protects, and to what extent it protects them. The Rule is slightly narrower, in a principled and historically consistent way, than it is normally perceived to be. It does require narrow construction of ambiguous penal statutes in some cases, but not for people who have a duty to know, and do, better. 